$$
\begin{gathered}
\text { 여성노인에서 운동프로그램이 심혈관계와 근골격계 } \\
\text { 그리고 삶의 질에 미치는 효과 } \\
\text { 정은경 } \\
\text { 전남대학교 의과대학 의학교육학교실 }
\end{gathered}
$$

\title{
The Effect of Exercise on Cardiovascular and Musculoskeletal Variables and Quality of Life in Elderly Women
}

\author{
Eun-Kyung Chung \\ Department of Medical Education, Chonnam National University Medical School

$$
=\text { ABST RACT }=
$$

Objectives: The aim of this study was to evaluate the effects of exercise on the cardiovascular and musculoskeletal variables and quality of life in elderly women.

Methods The study subjects were 22 in experimental group and 21 in the control group, all of who were aged 65 years and over. The subjects in the experimental group were under an exercise program 3 times a week for one year. To assess the effects of exercise in the study group, blood pressure, heart rate, lipid profile, bony metabolism, grip strength, flexibility, reaction time, and quality of life were measured.

Results Exercise showed the significant differences between experimental and control groups on the variables of the diastolic blood pressure, HDL-cholesterol, urinary deoxypyridinoline, flexibility, and quality of life. Compared to before the exercise in the study group, the urinary DPD level and quality of life were significantly improved at 3 months, and diastolic blood pressure, serum HDL-cholesterol, and flexibility were significantly improved by 1 year.

Conclusions The study results underscore the efficacy of exercise and the need for regular exercise programs that are designed for older persons.

Key words : Exercise, A ged, Blood pressure, HDL-cholesterol, Deoxypyridinoline

\footnotetext{
* 교신저자: 정은경, 501-746 광주광역시 동구 학1동 5번지, 전화: 062-220-4178 팩스: 062-236-3653

E-mail: ekcmedu@chonnam.ac.kr

본 논문은 전남대학교 병원 임상연구소 연구비 지원(CUHRI-U- 20034이) 의하여 연구되었음.
} 


\section{서 론}

우리나라 노인 인구는 꾸준히 증가하여 2000 년에 이미 65세 이상의 노인이 7\%를 상회하여 본격적인 고령화 사회(aging society)에 돌입하 였고, 2020년에는 14\%를 넘어 고령 사회(aged society로 진입할 것으로 전망된다. 이러한 인 구의 급속한 고령화 현상으로 인한 야기되는 여러 가지 노인 관련 문제 중에서 노인의 건 강문제는 중요한 관심의 대상이 되고 있대[1]. 특히 노인에서 보이는 가장 현저한 변화는 근 골격계의 변화로 이는 노인의 신체 기능저하, 기능장애와 기능상실 등으로 나타나 활동에 직접적인 영향을 주어 독립적인 일상생활을 저해할 뿐만 아니라 삶의 질에 위협을 주고 있어 간과할 수 없는 중요한 문제이대 [2].

따라서 노인의 삶의 질과 독립성을 향상시 키기 위해서 노인의 신체 기능 유지는 매우 중요하며, 건강상태와 운동능력을 고려하여 운 동을 실시하는 것이 필요하다[ 3].

지금까지 여러 역학적 연구를 통하여 노인 에서 운동에 의하여 신체의 다양한 영역에 긍 정적인 효과가 있다고 보고하고 있다. 노인에 서 운동에 의하여 심혈관계 기능이 향상될 뿐 아니라 $[4,5]$ 혈장 지질성분 및 체지방의 변화 등 심혈관계 위험인자 등의 개선 효과가 증명 되었고[6-8], 여러 가지 호르몬 및 신경전달물 질이 분비되어 인체의 면역기능을 강화시켜 질병의 위험을 감소시킨다[9]. 또한 운동은 우 울증 및 자아 존중감을 개선시킴으로써 노인 의 삶의 질을 향상시킬 뿐만 아니라[10], Sherman 등 11$]$ 은 75세 이상 노인에서도 운동 을 하면 수명의 연장에 도움이 된다고 보고하 였다.

그러나 선행연구에서는 노인에서 운동의 효 과를 주로 일부 측면에 국한되어 증명하였고, 단기간 운동을 실시한 후 운동 전후의 효과를 평가하여 비교적 장기간에 걸친 운동의 효과 를 설명할 수 없다는 문제점이 있다. 또한 노 화에 따른 신체기능 변화나 사회 심리적인 문
제를 겪을 가능성이 여성 노인이 남성 노인보 다 높음에도 불구하고 여성 노인만을 대상으 로 한 연구도 제한적이었다.

본 연구는 여성 노인을 대상으로 1년간 규칙 적인 운동을 실시한 후 심혈관계 및 근골격계 그리고 삶의 질에 미치는 영향을 파악하여 노 인 건강증진에 효과적인 방안을 마련하는데 기여하고자 하였다.

\section{대상 및 방법}

\section{1. 연구대상}

전라남도 일개 군에 총 103 개의 경로당이 있 는데, 이 중 2개의 경로당을 무작위로 뽑아 한 경로당은 운동 프로그램을 실시하는 실험군으 로, 또 다른 경로당은 대조군으로 선정하였다. 2곳의 경로당에 등록된 65세 이상의 노인들 중 6개월 내에 심장발작이나 뇌졸중이 없고, 운동과 보행이 가능하며, 운동으로 건강이 악 화될 것이라는 의사의 진단을 받지 않은 네 가지 조건에 모두 적합하면서 본 연구의 취지 를 이해하고 서면 동의한 노인들을 최종 연구 대상으로 하였으며 실험군 22명과 대조군 21 명이었다.

운동프로그램의 적용기간은 2003ㅕㅕㄴ 4월부터 2004년 3월까지 1년이었다.

\section{2. 연구방법}

1) 운동프로그램

본 연구에 사용한 운동프로그램은 미국스포 츠의학회[ 12]의 운동 가이드라인를 참고하였 다. 또한 노인의 체력요소를 감안하였으며, 전 문가의 의견을 들어 수정 보완하였다.

실험군에게 적용된 운동 프로그램은 집단으 로 시행하였으며, 스트레칭이 포함된 준비 운 동과 정리운동으로 시작과 마무리하였다. 본 운동은 상지운동과 하지운동으로 나눌 수 있 으며, 상지운동은 머리 돌리기, 앞으로 팔 올리 기, 옆으로 팔 올리기, 양팔을 펴서 앞으로 모 으는 동작, 양팔을 접어서 앞으로 모으는 동작, 
양팔을 펴서 위에서 함께 흔드는 동작, 팔꿈치 굽히기, 팔꿈치 펴기, 위에서 당기는 동작, 양 팔을 벌려 흔드는 동작, 어깨 올리기, 어깨 돌 리기, 손목 꺾어서 흔드는 동작, 양팔 벌려 손 뼉 치기, 팔을 안쪽으로 마는 동작 등이다. 또 한 하지운동은 한 박자씩 반대편 발을 터치하 기, 두 박자씩 반대편 발을 터치하기, 슬관절 들어올리기, 발가락 올리기, 한쪽 다리는 구부 리고 반대쪽 다리는 펴서 바닥에 닿는 동작, 다리 벌려 뛰고 모으는 동작, 무릎을 위로 접 는 동작, 다리를 앞뒤로 벌려 뛰는 동작, 다리 를 교차로 크로스해서 제자리로 돌아오는 동 작, 무릎을 구부렸다 일어나는 동작, 쪼그려 앉 기, 무릎을 안쪽으로 구부리면서 골반과 허리 를 움직이는 동작 등이다. 대조군에는 어떠한 조치도 가하지 않았으며, 평상시의 개인 활동 을 유지하였다.

준비운동 10 분, 본 운동 30 분, 정리운동 10 분 총 50 분 동안, 주 3 회씩 수행하도록 하였으며, 본 운동은 1주부터 3주까지는 15 분에서 30 분까 지 1주에 5분씩 증가, 4주부터 30분 동안 실시 되었다.

\section{2) 측정도구}

본 연구에서 노인에서의 운동 효과를 파악 하기 위해서 심혈관계 관련 지표로는 혈압과 심박동수, 혈청지질성분을, 근골격계 관련 지 표로는 골대사지표, 악력, 유연성, 민첩성을 그 리고 삶의 질에 대한 문항을 운동을 실시하기 전, 운동 실시 3개월 후, 그리고 1년 후의 각 시기에 모든 실험군과 대조군을 대상으로 측 정하였다.

혈압 및 심박수는 자동전체혈압계를 이용하 여 적어도 5 분 이상 휴식을 취한 후에 등받이 의자에 편하게 앉은 자세에서 1분 간격으로 오른쪽 상완에서 두 번 측정하였다. 혈압의 경 우 2회의 측정값이 $10 \mathrm{mmHg}$ 이상 차이가 나 면 3회 측정하여 그 측정값들의 평균을 실제 혈압치로 산정하였다. 12시간 이상 금식 후 채 혈 및 채뇨가 실시되었는데, 혈청지질성분으로
는 총 콜레스테롤, 중성 지질, 그리고 고밀도 콜레스테롤을 측정하였고, 골대사지표로는 칼 슘, 무기인, 오스테오칼신, 그리고 DPD (Deoxypyridinoli雨) 측정하였다. 악력은 악력 계(Grip D-TKK 5401, Japan)를 이용하여 측정 하였으며, 직립자세로 두발을 자연스럽게 벌린 다음 팔을 자연스럽게 내리고 악력계가 신체 나 옷에 닿지 않도록 하여 측정하였다. 유연성 은 전굴 유연성 측정기(Extension D-TKK 5403 , J apan)를 이용하였으며 발바닥을 측정기 의 발판에 붙이고 무릎을 펴고 앉은 후 윗몸 을 앞으로 구부리며 손으로 미끄럼판을 밀어 낸 후 밀려간 거리를 $\mathrm{cm}$ 단위로 측정하였다. 민첩성은 전방의 불빛을 보고 반응하는데 걸 리는 시간을 $\mathrm{msec}$ 로 측정하였다. 삶의 질은 Nelson 등[13]이 개발한 COOP Charts를 이용 하여 평가하였다. COOP Charts는 신체적 기능 (physical fitness), 감정상태(feding), 일상활동 (daily activity), 사회활동(social activity), 신체 통증(pain), 인지된 건강상태(overall health), 건 강의 변화(change in health), 사회적 지지( social support), 주관적 삶의 질(subjective quality of life) 등 9개 항목으로 구성되는데, 본 조사에서 는 진료결과를 알아보기 위한 항목인 건강의 변화를 제외하고 8개 항목을 사용하며, 각 항 목에 대해여 매우 좋음 1점, 좋음 2점, 보통 3 점, 나쁨 4점, 매우 나쁨 5점을 주었으며 8항목 의 합을 삶의 질 점수로 하였다.

\section{3. 분석방법}

수집된 자료는 SPSS for Windows 14.0을 이 용하여 분석하였다.

실험군과 대조군의 일반적 특성 및 생활습 관 변수에 대한 비교는 Chi-square test를 시행 하였고, 운동을 실시하기 전의 실험군과 대조 군의 측정치에 대한 비교는 Student t-test를 시행하였다.

운동참여에 따른 심혈관계 및 근골격계 지 표와 삶의 질 변화를 확인하고자 운동 실시 전, 운동 실시 3개월 후, 운동 실시 1년 후 측 
정하여 분석하였으며 반복측정 분산분석을 시 행하였다.

\section{결 과}

1. 연구대상자의 특성

1) 인구사회학적 특성

연구대상자는 연령별로는 65-74게가 실험군 에서는 $7.3 \%$, 대조군에서는 $81.0 \%$ 로 대부분을 차지하였고, 교육수준별로는 무학이 실험군에 서 $27.3 \%$, 대조군에서 $33.3 \%$ 를 차지하였다. 결 혼 상태는 실험군에서는 사별한 경우가 $63.6 \%$ 를 차지하였고, 대조군에서는 결혼하여 동거하 고 있는 경우가 61.9\%를 차지하였다.

규칙적인 운동은 실험군의 $40.9 \%$ 에서, 대조 군의 $42.9 \%$ 에서 하고 있는 것으로 조사되었다. 현재 흡연자는 실험군에서 $13.6 \%$, 대조군에서 $4.6 \%$ 이었고, 현재 음주자는 실험군에서 $18.2 \%$ 에서 대조군에서 $33.3 \%$ 이었다.

일반적 특성 및 생활습관 변수에서 실험군 과 대조군 사이에 유의한 차이가 없었다 (Table 1).
2) 운동 실시 전 심혈관계 및 근골격계 지 표와 삶의 질의 분포

본 연구에서 노인에서 운동에 의한 심혈관 계 및 근골격계 지표와 삶의 질의 변화를 파 악하기 위하여 측정된 지표는 Table 2와 같다.

운동 실시 전의 심혈관계 및 근골격계 지표 와 삶의 질에서 실험군과 대조군 사이에 유의 한 차이가 없었다.

2. 운동참여에 따른 심혈관계 및 근골격계 지표와 삶의 질 변화

1) 혈압 및 심박동수 변화

운동참여에 따른 혈압 및 심박동수 변화는 Table 3과 같다.

안정시 이완기 혈압의 경우 실험군에서 운 동 실시 전 $88.05 \mathrm{mmHg}$, 운동 실시 3개월 후 $86.68 \mathrm{mmHg}$, 운동 실시 1년 후 $83.73 \mathrm{mmHg}$ 로 감소하였으며, 대조군과 통계적으로 유의한 차 이를 보였다.

안정시 수축기 혈압, 맥압, 심박동수는 실험 군과 대조군간에 통계적으로 유의한 차이가 없었다.

Table 1. General characteristics in the experimental and control groups

Unit : $\mathrm{n}(\%)$

\begin{tabular}{|c|c|c|c|c|c|}
\hline & & & $\begin{array}{c}\text { Experimental } \\
\text { group } \\
(n=22)\end{array}$ & $\begin{array}{l}\text { Control } \\
\text { group } \\
(n=21)\end{array}$ & $p$-value \\
\hline \multirow[t]{6}{*}{ General characteristics } & Age(yr) & $65-74$ & $17(77.3)$ & $17(81.0)$ & 0.767 \\
\hline & & 75 over & $5(22.7)$ & $4(19.0)$ & \\
\hline & Education & Yes & $16(72.7)$ & 14(66.7) & 0.665 \\
\hline & & No & $6(27.3)$ & 7( 33.3) & \\
\hline & Marital status & Married & $8(36.4)$ & $13(61.9)$ & 0.094 \\
\hline & & Widowed & 14(63.6) & 8(38.1) & \\
\hline \multirow[t]{8}{*}{ Health habits } & Regular exercise & Yes & 9( 40.9) & $9(42.9)$ & 0.897 \\
\hline & & No & $13(59.1)$ & $12(57.1)$ & \\
\hline & Smoking & Yes & 3( 13.6) & $1(4.8)$ & 0.607 \\
\hline & & No & 19(86.4) & $20(95.2)$ & \\
\hline & A lcohol drinking & Yes & 4( 18.2) & 7( 33.3) & 0.255 \\
\hline & & No & 18(81.8) & $14(66.7)$ & \\
\hline & Periodic health ex & nYes & $11(50.0)$ & $14(66.7)$ & 0.268 \\
\hline & & No & $11(50.0)$ & 7(33.3) & \\
\hline
\end{tabular}


Table 2. Mean values of cardiovascular and musculoskeletal variables and quality of life before exercise in the experimental and control groups

Unit : mean \pm SD

\begin{tabular}{|c|c|c|c|}
\hline V ariables & $\begin{array}{l}\text { Experimental group } \\
\qquad(n=22)\end{array}$ & $\begin{array}{l}\text { Contro groupl } \\
\quad(n=21)\end{array}$ & p-value \\
\hline Systolic BP(mmHg) & $144.41 \pm 12.40$ & $149.19+12.40$ & 0.238 \\
\hline Diastolic BP(mmHg) & $88.05+10.64$ & $92.05+9.44$ & 0.200 \\
\hline Pulse pressure( $\mathrm{mmHg})$ & $56.36 \pm 7.84$ & $57.14 \pm$ & 0.768 \\
\hline Heart rate( beats/ min) & $78.91 \pm 11.51$ & $81.33+12.00$ & 0.503 \\
\hline Total cholesterol(mg/dL ) & $215.41 \pm 24.56$ & $203.48 \pm 27.70$ & 0.142 \\
\hline HDL - cholesterol ( mg/ dL ) & $43.09 \pm 8.02$ & $40.67 \pm \quad 7.07$ & 0.300 \\
\hline T riglyceride( mg/ dL ) & $147.77 \pm 51.83$ & $158.95+56.63$ & 0.503 \\
\hline LDL - cholesterol ( mg/ dL ) & $123.06 \pm 23.86$ & $111.83 \pm 34.72$ & 0.221 \\
\hline Calcium( mg/ dL ) & $9.09 \pm \quad 0.34$ & $9.21 \pm \quad 0.27$ & 0.218 \\
\hline Phosphorus( mg/dL ) & $3.81 \pm$ & $3.86 \pm$ & 0.733 \\
\hline Osteocalcin(ng/ mL ) & $11.14 \pm$ & $13.02 \pm$ & 0.113 \\
\hline Deoxypyridindine(DPD) (mM DPD/mM creatinine) & $6.37 \pm$ & $6.45+$ & 0.916 \\
\hline Grip strength( $\mathrm{kg})$ & $9.58+$ & $11.04 \pm$ & 0.268 \\
\hline Sitting trunk flexion(cm) & $11.50 \pm \quad 6.22$ & $9.02 \pm \quad 6.46$ & 0.208 \\
\hline Reaction time( msec) & $723.05+136.37$ & $720.19+204.28$ & 0.957 \\
\hline Quality of life( score) & $20.23+\quad 2.52$ & $20.10 \pm \quad 3.96$ & 0.898 \\
\hline
\end{tabular}

Table 3. Comparison of blood pressure and heart rate between the experimental and control groups

Unit : mean \pm SD

\begin{tabular}{cccc}
\hline \hline Variables & Pretreatment & Post-3 months & Post- 1 year \\
\hline Systolic BP $(\mathrm{mmHg})$ & $149.19 \pm 14.30$ & $144.57 \pm 15.78$ & $148.76 \pm 14.28$ \\
$\begin{array}{c}\text { Control } \\
\text { Experimental }\end{array}$ & $144.41 \pm 12.40$ & $142.50 \pm 14.10$ & $135.18 \pm 13.20$ \\
Diastolic BP $(\mathrm{mmHg})^{*}$ & & & \\
Control & $92.05 \pm 9.44$ & $90.38 \pm 8.70$ & $92.00 \pm 8.93$ \\
Experimental & $88.05 \pm 10.64$ & $86.68 \pm 8.47$ & $83.73 \pm 8.18$ \\
Pulse pressure(mmHg) & & & \\
Control & $57.14 \pm 9.31$ & $54.19 \pm 12.86$ & $56.76 \pm 10.40$ \\
Experimental & $56.36 \pm 7.84$ & $55.82 \pm 11.92$ & $51.45 \pm 11.03$ \\
Heart rate(beats/min) & & & \\
Control & $81.33 \pm 12.00$ & $76.95 \pm 8.96$ & $80.33 \pm 10.54$ \\
Experimental & $78.91 \pm 11.51$ & $79.41 \pm 11.16$ & $71.55 \pm 7.30$ \\
\hline
\end{tabular}

*Significant between experimental and control groups by time

2) 혈청지질성분변화

운동참여에 따른 혈청지질성분의 변화는 Table 4와 같다.
고밀도 콜레스테롤의 경우 실험군에서 운동 실시 전 $43.09 \mathrm{mg} / \mathrm{dL}$, 운동 실시 3개월 후 $47.36 \mathrm{mg} / \mathrm{dL}$, 운동 실시 1년 후 $5109 \mathrm{mg} / \mathrm{dL}$ 로 
6 여성노인에서 운동프로그램이 심혈관계와 근골격계 그리고 삶의 질에 미치는 효과

Table 4. Comparison of lipid profiles between the experimental and control groups

Unit : mean $\pm S D$

\begin{tabular}{lcrc}
\hline \hline V ariables & Pretreatment & Post- 3months & Post- 1year \\
\hline $\begin{array}{c}\text { Total Cholesterol }(\mathrm{mg} / \mathrm{dL}) \\
\quad \text { Control }\end{array}$ & $203.41 \pm 27.70$ & $200.00 \pm 25.86$ & $204.57 \pm 29.48$ \\
$\quad$ Experimental & $215.41 \pm 24.54$ & $212.14 \pm 29.78$ & $196.86 \pm 26.15$ \\
HDL - Cholesterol(mg/dL) & & & \\
$\quad$ Control & $40.67 \pm 7.07$ & $41.10 \pm 6.62$ & $42.95 \pm 10.55$ \\
$\quad$ Experimental & $43.09 \pm 8.02$ & $47.36 \pm 8.46$ & $51.09 \pm 10.88$ \\
Triglyceride( $\mathrm{mg} / \mathrm{dL})$ & & & \\
$\quad$ Control & $158.95 \pm 56.53$ & $179.62 \pm 82.48$ & $187.38 \pm 65.76$ \\
$\quad$ Experimental & $147.77 \pm 51.83$ & $155.91 \pm 51.73$ & $140.36 \pm 55.27$ \\
L DL- Cholesterol $(\mathrm{mg} / \mathrm{dL})$ & & & \\
$\quad$ Control & $111.83 \pm 34.72$ & $99.03 \pm 36.71$ & $95.16 \pm 34.80$ \\
$\quad$ Experimental & $123.06 \pm 23.86$ & $112.80 \pm 31.32$ & $98.98 \pm 24.00$ \\
\hline
\end{tabular}

*Significant between experimental and control groups by time

Table 5. Comparison of bone metabolism marker between the experimental and control groups

Unit : mean $\pm \mathrm{SD}$

\begin{tabular}{|c|c|c|c|}
\hline V ariables & P retreatment & Post- 3months & Post- lyear \\
\hline \multicolumn{4}{|l|}{ Calcium( mg/dL ) } \\
\hline Control & $9.21 \pm 0.27$ & $8.63+0.24$ & $8.74 \pm 0.33$ \\
\hline Experimental & $9.09 \pm 0.34$ & $8.85+0.42$ & $8.95+0.31$ \\
\hline \multicolumn{4}{|l|}{ Phosphorus( mg/ dL) } \\
\hline Control & $3.84 \pm 0.55$ & $3.78+0.40$ & $4.03+0.43$ \\
\hline Experimental & $3.86 \pm 0.31$ & $3.75+0.36$ & $3.96 \pm 0.44$ \\
\hline \multicolumn{4}{|l|}{ Osteocalcin(ng/mL ) } \\
\hline Control & $13.02 \pm 4.11$ & $11.64 \pm 4.43$ & $9.70 \pm 4.05$ \\
\hline Experimental & $11.14 \pm 3.50$ & $10.34 \pm 3.61$ & $8.23+2.76$ \\
\hline \multicolumn{4}{|c|}{ Deoxypyridinoline( mM DPD/mM creatinine) ${ }^{*}$} \\
\hline Control & $6.45 \pm 2.61$ & $6.07 \pm 3.25$ & $6.17 \pm 2.59$ \\
\hline Experimental & $6.37 \pm 2.36$ & $4.45+1.98$ & $4.09 \pm 1.57$ \\
\hline
\end{tabular}

* Significant between experimental and control groups by time

증가하였으며, 대조군과 통계적으로 유의한 차 이를 보였다.

총 콜레스테롤과 중성지질, 저밀도 콜레스테 롤의 경우는 실험군과 대조군간에 통계적으로 유의한 차이가 없었다.

3) 골대사지표의 변화
운동참여에 따른 골대사지표의 변화는 Table 5 와 같다.

요중 $\mathrm{DPD}$ 는 실험군에서 운동실시 전 6.37 $\mathrm{nM} \mathrm{DPD} / \mathrm{mM}$ creatinine, 운동실시 3개월 후 $4.45 \mathrm{nM} \mathrm{DPD} / \mathrm{mM}$ creatinine, 운동실시 1년 후 $4.09 \mathrm{nM} \mathrm{DPD} / \mathrm{mM}$ creatinine으로 감소하였으 며, 대조군과 통계적으로 유의한 차이를 보였 
Table 6. Comparison of physical fitness between the experimental and control groups

Unit : mean $\pm \mathrm{SD}$

\begin{tabular}{lrrrrrr}
\hline \hline Variables & Pretreatment & \multicolumn{2}{c}{ Post-3months } & \multicolumn{2}{c}{ Post- 1year } \\
\hline Grip strength $(\mathrm{kg})$ & & & & & & \\
$\quad$ Control & $11.04 \pm$ & 4.45 & $13.91 \pm$ & 4.36 & $13.17 \pm$ & 3.72 \\
$\quad$ Experimental & $9.58 \pm$ & 4.12 & $15.12 \pm$ & 5.23 & $15.17 \pm$ & 4.95 \\
Sitting trunk flexion $(\mathrm{cm})^{*}$ & & & & & & \\
$\quad$ Control & $9.02 \pm$ & 6.46 & $9.86 \pm$ & 4.65 & $11.02 \pm$ & 4.97 \\
$\quad$ Experimental & $11.50 \pm$ & 6.22 & $12.78 \pm$ & 5.57 & $16.52 \pm$ & 6.49 \\
Reaction time (msec) & & & & & & \\
$\quad$ Control & $720.19 \pm 204.28$ & $639.29 \pm 142.93$ & $455.33 \pm 101.20$ \\
$\quad$ Experimental & $723.05 \pm 136.37$ & $566.00 \pm 220.04$ & $445.95 \pm 92.96$ \\
\hline
\end{tabular}

* Significant between experimental and control groups by time

Table 7. Comparison of quality of life between the experimental and control groups

Unit : mean \pm SD

\begin{tabular}{lccc}
\hline \hline V ariables & Pretreatment & Post- 3months & Post- 1year \\
\hline Quality of life( score) ${ }^{*}$ & & & \\
Control & $20.10 \pm 3.96$ & $19.52 \pm 3.28$ & $21.14 \pm 3.37$ \\
Experimental & $20.23 \pm 2.53$ & $17.55 \pm 4.26$ & $17.72 \pm 3.78$ \\
\hline
\end{tabular}

* Significant between experimental and control groups by time

다.

혈청 칼슘, 무기인, 오스테오칼신의 경우는 실험군과 대조군간에 통계적으로 유의한 차이 가 없었다.

4) 악력, 유연성, 민첩성의 변화

운동참여에 따른 악력, 유연성 그리고 민첩 성 변화는 Table 6과 같다.

유연성의 경우 실험군에서 운동 실시 전 $11.50 \mathrm{~cm}$, 운동 실시 3개월 후 $12.78 \mathrm{~cm}$, 운동 실시 1년 후 $16.52 \mathrm{~mm}$ 으로 증가하였으며, 대조 군과 통계적으로 유의한 차이를 보였다.

악력과 민첩성의 경우는 실험군과 대조군간 에 통계적으로 유의한 차이가 없었다.

5) 삶의 질 변화

운동참여에 따른 통증정도 및 삶의 질 변화
는 Table 7과 같다.

삶의 질의 경우 실험군에서 운동 실시 전 20.23점, 운동 실시 3개월 후 17.55점, 운동 실시 1년 후 17.72점으로 대조군과 통계적으로 유의 한 차이를 보였다.

3. 실험군에서 시간에 따른 심혈관계 및 근 골격계 지표와 삶의 질 변화

실험군과 대조군간에 통계적으로 유의한 차 이를 보였던 심혈관계 및 근골격계 지표와 삶 의 질의 시간에 따른 결과는 Table 8과 같다. 요중 DPD와 삶의 질의 지표는 운동 실시 전 에 비해 운동 실시 3개월 후에 통계적으로 유 의하게 향상되었다. 반면에 안정시 이완기 혈 압과 고밀도 콜레스테롤, 그리고 유연성의 지 표의 경우는 운동 실시 전에 비해 운동 실시 1년 후에 통계적으로 유의하게 향상되었다. 
Table 8. Improvement of cardiovascular and musculoskeletal variables and quality of life according to time in experimental group

\begin{tabular}{|c|c|c|c|c|}
\hline \multirow[b]{2}{*}{ V ariables } & \multicolumn{2}{|c|}{ Post- 3months } & \multicolumn{2}{|c|}{ Post- 1year } \\
\hline & $\begin{array}{c}\text { Mean } \\
\text { difference }\end{array}$ & $\begin{array}{c}\text { Improvement } \\
(\%)\end{array}$ & $\begin{array}{c}\text { M ean } \\
\text { difference }\end{array}$ & $\begin{array}{l}\text { Improvement } \\
(\%)\end{array}$ \\
\hline Diastolic BP(mmHg) & -1.37 & -1.6 & -4.32 & -4.9 \\
\hline HDL - Cholesterol ( mg/ dL ) & 4.27 & 9.9 & 8.00 & 18.6 \\
\hline Deoxypyridindine(mM DPD/mM creatinine) & -1.92 & $-30.1^{*}$ & -2.28 & -35.8 \\
\hline Sitting trunk flexion(cm) & 1.28 & 11.1 & 5.02 & 43.7 \\
\hline Quality of life( score) & -2.68 & -13.2 & -2.51 & -12.4 \\
\hline
\end{tabular}

* Significant change pre vs. post-treatment

\section{고 찰}

운동참여에 따른 심혈관계 및 근골격계 지 표와 삶의 질의 변화를 분석한 결과 안정시 이완기 혈압, 고밀도 콜레스테롤, 유연성, 요중 $\mathrm{DPD}$, 그리고 삶의 질이 향상되었다. 특히 운 동실시 전에 비해 요중 DPD와 삶의 질은 운 동 실시 3개월 후에, 안정시 이완기 혈압과 고 밀도 콜레스테롤, 그리고 유연성은 운동 실시 1년 후에 통계적으로 유의한 결과가 나타났다.

운동이 혈압에 미치는 효과에 대해서 Blumenthal 등[14]은 에어로빅 운동 후 노인의 이완기 혈압에서 긍정적인 변화가 나타났다고 보고한 반면, Stevenson과 Topp[15냔 노인에 게 저 강도 운동프로그램을 9개월간 실시한 결과 수축기 혈압, 이완기 혈압에 유의한 차이 가 없다고 보고하였다. 이러한 연구결과의 차 이는 연구대상자의 선정, 운동 프로그램 실시 기간 그리고 노인의 특성에 기인한 것으로 사 료된다. Fagard[16]에 의하면 규칙적인 유산소 운동시 정상 혈압군에서 $4 / 4 \mathrm{mmHg}$ (수축기/ 이완기)의 감압효과가 나타났고 고혈압군에서 는 $11 / 6 \mathrm{mmHg}$ 으로 더 큰 감압효과가 나타난 다고 한다. 또한 본 연구에서 운동 실시 전에 비해 운동 실시 3개월 후에는 유의한 차이가 없었으나 운동 실시 1년 후에 이완기 혈압이 유의한 차이를 보여 운동 실시 기간에 따라서 결과가 달라질 수 있음을 보여주었으며, 노인
에서는 white coat effect가 다른 연령층에 비해 커서 일반적인 혈압 측정으로 운동의 효과를 평가하기에는 어려움이 있다는 보고도 있다 [17, 18].

본 연구의 고밀도 콜레스테롤의 결과는 혈 중 지단백질 농도가 유의하게 변화되기 위해 서는 장시간의 운동을 필요한 것으로 보고하 고 있는 Stucchi 등[19]의 연구결과와 일치하 였다.

본 연구에서는 골대사지표에 대한 효과를 골형성을 나타내는 오스테오칼신과 골흡수를 나타내는 소변의 DPD로 측정하였는데, 이 지 표들은 최근 골대사 연구에 많이 사용되는 대 표적인 지표일 뿐 아니라, 골밀도의 변화가 있 기 몇 달 전부터 먼저 변화가 나타나므로 골 다공증의 예방과 치료의 측면에서도 유용하게 사용되고 있다[20]. 특히 노인의 골절의 경우 에 그 위험도는 골의 재흡수 지표가 골형성 지표에 비해 더 중요하다고 알려져 있어 본 연구에서 나타난 요중 DPD의 감소는 아주 의 의 있는 결과라고 할 수 있다.

유연성은 실험군에서 대조군보다 증가하였 고, 그 변화가 운동 실시 후에 의미 있게 나타 났다. 그러나 이[21]의 연구에서는 노인에서 운동 실시 9주 후에 유연성이 증진된 결과를 보였는데, 이는 운동의 빈도나 강도의 차이 때 문으로 사료된다. 본 연구에서는 1주일에 3회 운동을 실시한 반면 이[21]의 연구에서는 1주 
일에 5회 운동을 실시하였다.

노인에서 운동은 신체적 기능뿐만 아니라 삶의 질 지표에도 긍정적인 결과를 보였는데 이는 운동 프로그램 후 삶의 질이 유의하게

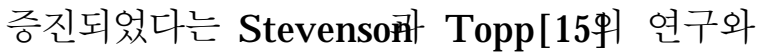
이[21]의 연구 결과와 일치하였다.

본 연구는 다음과 같은 몇 가지 제한점을 가 지고 있다. 첫째, 노인에서 운동을 실시할 때 적절한 운동 강도 설정이 중요하며, 이를 위해 서 최대 산소 섭취량이나 최대 심박수를 기준 으로 운동 강도를 정해야 하는 것으로 되어 있으나 본 연구에서는 운동 강도를 운동 중 힘든 정도를 주관적으로 나타내는 주관적 인 지도에 따라 조절하였다. 그러나 Tanuton 등 [22]에 의하면 최대 산소 섭취량 측정의 경우 는 근력이 약한 노인에게 적용하는데 어려움 이 있고, 최대 심박수의 경우는 매우 오차가 심하게 날 수 있으며, 오히려 주관적 인지도가 운동 강도를 가늠하는 좋은 지표가 될 수 있 다고 하였다. 둘째 일부 지역 경로당의 여자 노인을 대상으로 연구하였으므로 일반 노인에 게 일반화하기에는 제한이 있을 수 있다. 셋째, 운동 프로그램을 실시한 실험군과 그렇지 않 은 대조군이 일반적 특성 및 생활습관에서 유 의한 차이가 없었지만, 그 외의 운동 프로그램 에 영향을 미칠 수 있는 요인들을 통제하지 못했다는 제한점이 있다.

본 연구에서 노인에게 일정기간 규칙적인 운동을 실시한 후 심혈관계 및 근골격계 지표 와 삶의 질에 미치는 영향을 파악한 결과, 일 반적인 노화과정에 있는 대조군의 노인들에 있어서 심혈관계 및 근골격계 지표와 삶의 질 측정값이 대부분 변화가 없거나 저하된 반면, 운동 프로그램을 적용한 실험군에서는 향상되 는 양상을 보였다. 따라서 노인에서 운동은 신 체적 기능뿐만 아니라 삶의 질에도 긍정적인 영향을 미치므로 노인의 건강상태와 운동능력 을 감안하여 운동프로그램을 지속적으로 실시 하는 것이 필요하다.

\section{요 약}

본 연구는 여성 노인에서 1년간 규칙적인 운 동을 실시한 후 심혈관계 및 근골격계 지표와 삶의 질에 미치는 영향을 파악하고자 전라남 도 일개 군에 있는 2곳의 경로당에 등록된 65 세 이상의 노인들로 실험군 22명과 대조군 21 명을 대상자로 하였다. 운동 프로그램을 실험 군에게만 주 3회, 1년 동안 적용하였으며, 운동 실시에 따른 혈압, 심박동수, 혈청지질성분, 골 대사지표, 악력, 유연성, 민첩성, 삶의 질 지표 변화를 확인하고자 운동실시 전, 운동 실시 3 개월 후, 운동 실시 1년 후 측정하여 분석하였 다.

운동참여에 따른 심혈관계 및 근골격계 지 표와 삶의 질 변화를 측정하여 분석한 결과 안정시 이완기 혈압, 고밀도 콜레스테롤, 유연 성, 요중 $\mathrm{DPD}$, 그리고 삶의 질의 지표가 향상 되었다. 특히 운동 실시 전에 비해 요중 DPD 와 삶의 질의 지표는 운동 실시 3개월 후에, 안정시 이완기 혈압과 고밀도 콜레스테롤, 그 리고 유연성의 지표의 경우는 운동 실시 1년 후에 통계적으로 유의한 결과가 나타났다.

이상의 결과로 볼 때 노인에서 운동은 신체 적 기능뿐만 아니라 삶의 질에도 긍정적인 영 향을 미치므로 노인의 건강상태와 운동능력을 감안하여 운동프로그램을 지속적으로 실시하 는 것이 필요하다.

\section{참고문헌}

1. 김효정, 김명애, 박경민. 노인의 만성동통 유 무에 따른 건강상태 및 일상생활장애 비교. 한국농촌의학회지 1999; 24(1) : 79-89

2. Keller $M$, Leventhal $H$, Leventhal $E$. Research on the health problems of aging and how people cope with them. University of Winsconsin, 1991

3. Ette AM, Branch LG. The Framingham disability study: II. Physical disability 
among the aging. A merican Journal of Public Health 1981; 71( 11) : 1211- 1216

4. Ogawa T, Spina RJ, Martin WH 3rd, Kohrt WH, Schechtman KB, Holloszy JO, Ehsani AA. Effects of aging, sex and physical training on cardiovascular responses to exercise. Circulation 1992; 86( 2) : 494- 503

5. Hagberg J M, Graves JE, Limacher $M$, Woods DR, Leggett SH, Cononie C, Gruber JJ, Pollock ML. Cardiovascular responses of 70 - to 79 - yr old men and women to exercise training. Journal of A pplied Physiology 1989; 66( 6) : 2589- 2594

6. Katzel LI, Bleecker ER, Colman EG, Rogus EM, Sorkin JD, Goldberg AP. Effects of weight loss vs. aerobic exercise training on risk factors for coronary disease in healthy, obese, middle-aged and older men. a randomized controlled trial. JAMA 1995; 274(24) : 1915- 1921

7. Schwartz RS, Shuman WP, Larson V, Cain K, Fellingham GW, Beard JP, Kahn SE, Stratton JR, Cerqueira $M$, A brass IB. The effects of intensive endurance exercise training on body fat distribution in young and older men. Metabolism: clinical \& experimental 1991; 40( 5) : 545- 551

8. Seals DR, A llen WK, Hurley BF, Dalsky GP, Ehsani A A, Hagberg JM. Elevated high-density lipoprotein cholesterol levels in older endurance athletes. A merican J ournal of Cardiology 1984; 54(3) : 390-393

9. Woods JA, Ceddia MA, Wolters BW, Evans JK, Lu Q. McA uley E. Effects of 6 months of moderate aerobic exercise training on immune function in the elderly. Mechanisms of A geing and
Development 1999; 109( 1) : 1- 19

10. Spirduso WW, Cronin DL. Exercise dose response effects on quality of life and independent living in older adults. Medicine \& Science in Sports \& Exercise 2001; 33( 1) : S598- 608

11. Sherman SE, D'A gostino RB, Cobb JL, Kannel WB. Does exercise reduce mortality rates in the elderly? Experience from the Framingham Heart Study. American Heart Journal 1994; 128(5): 965- 972

12. A merican College of Sports Medicine. ACSM's Health/Fitness F acility Standards and Guideline 2nd ed. 1997

13. Nelson E, Wasson J, Kirt J. Keller A, Clark D, Dierich A, Stewart A, Zubkoff $M$. Assessment of function in routine clinical description of the COOP Chart method and preliminary findings. Journal of Chronic Disease 1987; 40S( 1) : 55S- 63 S

14. Blumenthal JA, Emery CF, Madden DJ, George LK, Coleman RE, Riddle MW, Mckee DC, Reasoner J, Williams RS. Cardiovascular and behavioral effects of aerobic exercise training in healthy older men and women. Journal of Gerontology 1989; 44(5) : M 146- 157

15. Stevenson JS, Topp R. Effect of moderate and low intensity long-term exercise by older adult. Research in Nursing \& Health 1990; 13(4) : 209- 218

16. Fagard RH. Exercise Characteristics and the blood pressure response to dynamic physical training. Medical \& Science in Sports \& Exercise 2001; 33: S484- 492

17. A ihara A, Imai $Y$, Sekino $M, K$ ato J, Ito $S$, Ohkubo $T$, Tsuji I, Satoh $H$, Hisamichi S, Nagai K. Discrepancy 
between screening blood pressure and ambulatory blood pressure: a community-based study in Ohasama. Hypertension Research-clinical \& experimental 1998; 21( 2) : 127- 136

18. Mansoor GA, McCabe EJ, White WB. Determinants of the white coat effect in hypertensive subjects. Journal of Human Hypertension 1996; 10( 2) : 87- 92

19. Stucchi AF, Terpstra AH, Foxall TL, Nicolosi RJ, Smith SC. The effect of exercise on plasma lipids and LDL subclass metabolism in miniature swine. Medicine \& Science in Sports \& Exercise 1999; 23( 5) : 552- 561
20. Looker AC, Bauer DC, Chesnut CH 3rd, Gunberg CM, Hochberg MC, Klee G, Keerekoper M, Watts NB, Bell NH. Clinical use of biochemical markers of bone remodelling: current status and future direction. Osteoporossis Internationa/2000; 11( 6) : 467-480

21. 이숙자. 노인의 건강증진을 위한 율동적 운동프로그램의 적용효과. 대한간호학회지 2000; 30( 3) 766- 788

22. Tanuton JE, Martin AD, Rhodes EC, Wolski LA, Donelly $M$, Elliot J. Exercise for the older woman: choosing the right prescription. British Journal of Sports Medicine 1997; 31( 1) : 5- 10 